\title{
Relationships between substance use, anxiety, depression and stress by public university workers
}

\author{
Relações entre o uso de substâncias, ansiedade, depressão e estresse por trabalhadores de universidade pública
}

Relaciones entre el uso de sustancias, ansiedad, depresión y estrés por parte de trabajadores de universidades públicas

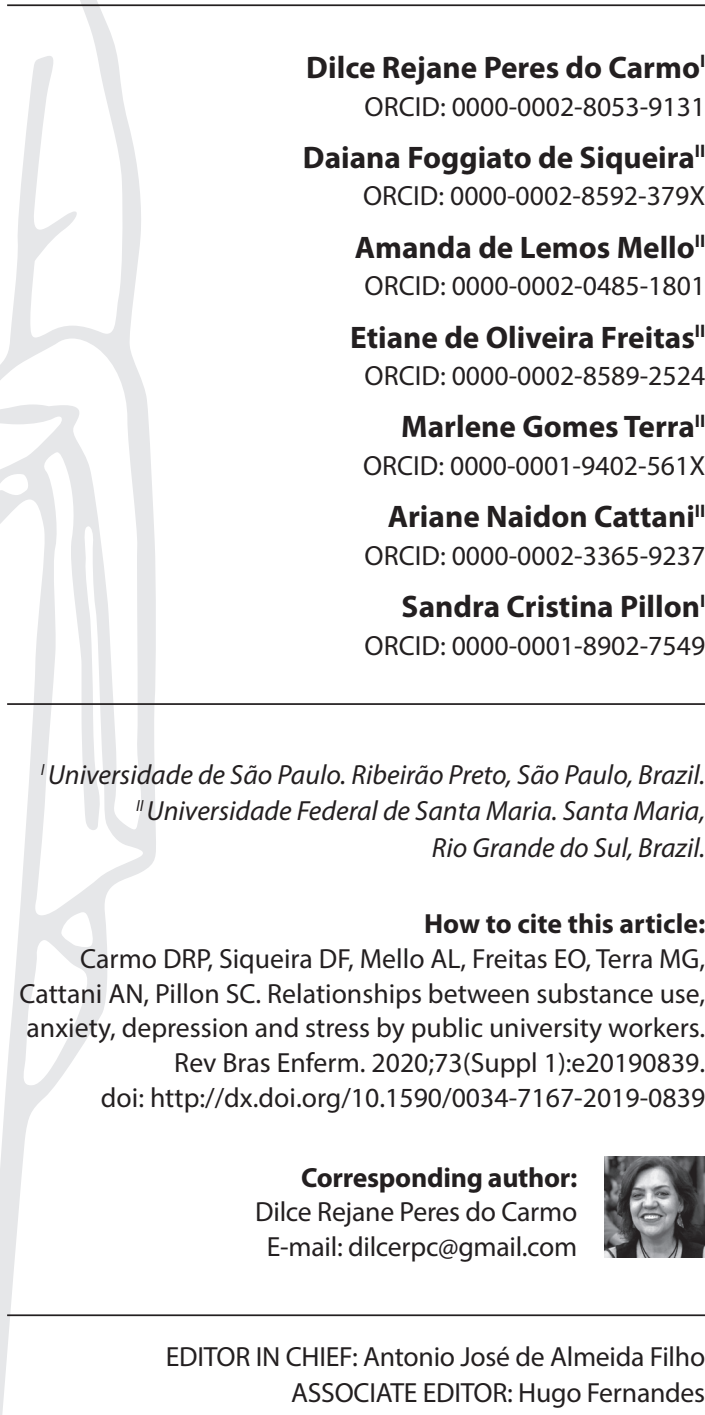

Submission: 02-12-2020

Approval: 07-22-2020

\begin{abstract}
Objective: To evaluate the relationship between psychoactive substance use, anxiety, depression and stress by workers at a Brazilian public university. Methods: This is a crosssectional study with a quantitative approach, carried out with 345 workers from a public higher education institution, located in a city in the interior of the state of Rio Grande do Sul, Brazil. Results: Professionals with an average age of 38.9 years, 187 (54.2\%) were women, 163 (47.2\%) were single, 186 (53.9\%) professed the Catholic religion, $223(64.8 \%)$ had graduate school education. Of the workers, $122(35.4 \%)$ considered their work to be stressful. The use of alcohol in the binge pattern (monthly) and heavy episodic drinking (weekly) were higher among workers with higher levels of anxiety, depression and stress. Conclusion: The use of alcohol in its different forms, stress, depression and anxiety show particularities that must be evaluated and recognized among the worker's health problems.
\end{abstract}

Descriptors: Nursing; Mental Health; Related Disorders Substance Use; Workers; Depression.

\section{RESUMO}

Objetivo: Avaliar as relações entre uso de substâncias psicoativas, ansiedade, depressão e estresse por trabalhadores de uma universidade pública brasileira. Método: Trata-se de um estudo do tipo transversal, de abordagem quantitativa, realizado com 345 trabalhadores de uma instituição de ensino superior pública, localizada em um município do interior do estado do Rio Grande do Sul, Brasil. Resultados: Profissionais tinham média de idade de 38,9 anos, $187(54,2 \%)$ eram mulheres, $163(47,2 \%)$ solteiros, $186(53,9 \%)$ professavam a religião Católica, 223 (64,8\%) possuíam formação em pós-graduação. Dos trabalhadores, $122(35,4 \%)$ consideraram que seu trabalho era estressante. O uso de álcool no padrão binge (mensal) e o beber episódico pesado (semanal) foram maiores entre os trabalhadores com maiores níveis de ansiedade, depressão e estresse. Conclusão: Uso de álcool em suas diferentes formas, estresse, depressão e ansiedade trazem particularidades que devem ser avaliadas e reconhecidas dentre os problemas de saúde do trabalhador.

Descritores: Enfermagem; Saúde Mental; Transtornos Relacionados ao Uso de Substâncias; Trabalhadores; Depressão.

\section{RESUMEN}

Objetivo: evaluar la relación entre el uso de sustancias psicoactivas, ansiedad, depresión y estrés por parte de los trabajadores de una universidad pública brasileña. Método: Este es un estudio transversal con un enfoque cuantitativo, realizado con 345 trabajadores de una institución pública de educación superior, ubicada en una ciudad en el interior del estado de Rio Grande do Sul, Brasil. Resultados: Profesionales con una edad promedio de 38.9 años, 187 (54.2\%) eran mujeres, 163 (47.2\%) solteros, 186 (53.9\%) profesaban la religión católica, $223(64.8 \%)$ tenían título de posgrado. De los trabajadores, $122(35,4 \%)$ consideraron que su trabajo era estresante. El consumo de alcohol en el binge drinking (mensual) y el consumo excesivo episódico - CEE (semanal) fueron mayores entre los trabajadores con mayores niveles de ansiedad, depresión y estrés. Conclusión: El consumo de alcohol en sus diferentes formas, el estrés, la depresión y la ansiedad traen particularidades que deben ser evaluadas y reconocidas entre los problemas de salud del trabajador.

Descriptores: Enfermería; Salud Mental; Trastornos Relacionados con Sustancias; Trabajadores; Depresión. 


\section{INTRODUCTION}

Alcohol, considered the most used substance by more than half of the population in several countries ${ }^{(1)}$, is one of the biggest risk factors for the development of diseases that results in high mortality rates. It is estimated that the consequences of alcohol use have resulted in nearly three million deaths (5.3\% of all deaths) worldwide, and 132.6 million by the Disability-Adjusted Life Years - DALY, representing $5.1 \%$ of all the DALY in the last year. In addition, 2.3 billion people were current drinkers, of which $49 \%$ of the cases attributed to the DALY were related to the consequences of alcohol use, chronic noncommunicable diseases (CNCD) and mental illness ${ }^{(1-2)}$

Another major concern in relation to the use of alcohol and/or other substances in their different consumption patterns, in addition to health issues, is the social consequence that these drugs cause mainly in the context of labor relations. Regardless of whether consumption has occurred or not at the workplace, it has repercussions on overall productivity and the workforce (triggering poor performance in the execution of tasks, accidents or injuries, poor service, high employee turnover and increased health costs) ${ }^{(3-4)}$.

Evidence showed that $15 \%$ of the workers had problems such as absenteeism and sick leave attributed to the use of alcohol and/or other drugs and $18 \%$ due to depression and stress. There was also an increased risk for the occurrence of accidents in the workplace among this group ${ }^{(3)}$. In this context, between 20 and $25 \%$ of work accidents worldwide were directly associated with people who were under the influence of some type of substance. Still, $3 \%$ to $5 \%$ of the workers' population had diagnostic criteria for alcohol dependence syndrome (ADS), linked to the consequences in the work environments such as delays, interpersonal conflicts, low productivity, pressure on co-workers, an insecure environment (violence, possible violence, possible assault and battery) and costs with dismissals and indemnities ${ }^{(1,4)}$.

In general, the use of alcohol and other substances in their different consumption patterns inhibits or hinders the ability of professionals to perform their activities effectively in the workplace ${ }^{(5)}$. This use interferes with the quality and performance of the functions assigned to workers, reflecting on their productivity. Heavy drinking the night before results in a high concentration of alcohol in the bloodstream leading to "hangover" effects (headaches, tremors, nausea and vomiting, as well as irritability, concentration problems and fatigue), which consequently, on the following day, appreciably affects work performance skills, frequency, performance and relationships with colleagues. In administrative and/ or economic terms, it has been of great interest to know which factors are related to the use of alcohol and/or other substances ${ }^{(6)}$.

Social and health costs are high, Brazil loses financially around 19 billion dollars (US \$) per year due to accidents, absenteeism (absence from work), presenteeism (presence at work but at reduced capacity) and diseases caused by drug use ${ }^{(7)}$. The Ministry of Social Security identified that between 2006 and 2014, about 350 thousand Brazilians were removed from their work activities due to problems related to drug use. In this period, the percentage of sick pay, due to mental (anxiety and depression) and behavioral disorders due to the use of psychoactive substances, in particular, that of multiple drugs, practically doubled (from $27.7 \%$ to $50.1 \%)^{(8)}$.
Depression and stress are considered psychological problems in contemporary society, and their triggering and evolution may be associated with experiences in the work context. When investigating the health conditions of the workers, a study revealed that $20.3 \%$ had symptoms of anxiety, $21.9 \%$ had depressive symptoms, $13.2 \%$ met diagnostic criteria for problematic alcohol use and $18.7 \%$ had high levels of exposure to occupational stress ${ }^{(9)}$.

In this sense, it has been well known that depression, stress, anxiety and the problematic use of psychoactive substances are responsible for rates of illness and absenteeism related to the work context. From the recognition of the relationship between the occurrence of mental disorders and working conditions, it will be possible to think about preventive strategies and timely interventions to minimize or prevent such problems $s^{(10)}$.

It is worth mentioning that there are several studies in the literature that involve the use of alcohol, stress, depression and anxiety ${ }^{(11-13)}$; however, studies that evaluate heavy episodic drinking (HED) and use in the binge pattern are still incipient, which justifies the development of the present work. Thus, it is essential to know what are the health behavior indicators in the relationship between depression, stress, anxiety and substance use, considering that they are relevant for the prevention of mental health problems among workers.

HED refers to the consumption of five or more doses of alcoholic beverages for men and women on a single occasion at least once in the last month and at least once a week ${ }^{(1)}$. The binge pattern refers to the consumption of six or more doses of alcohol on a single occasion at least once a month over a period of approximately two hours, according to the definition of the National Institute on Alcohol Abuse and Alcoholism (NIAAA) ${ }^{(14)}$.

\section{OBJECTIVE}

To evaluate the relationship between psychoactive substance use, anxiety, depression and stress by workers at a Brazilian public university.

\section{METHOD}

\section{Ethical aspects}

The ethical aspects were respected, as recommended by the Resolution n. 466/12 of the National Health Council. The study was approved by the Research Ethics Committee and all participants signed the Free and Informed Consent Form (FICF).

\section{Type of Study}

This is a cross-sectional study with a quantitative approach. The study was carried out in a public Higher Education Institution $(\mathrm{HEl})$, located in a city in the interior of the State of Rio Grande do Sul, Brazil.

\section{Population, sample, eligibility criteria}

At the time of data collection, at the university there were 1632 Administrative Technicians in Education (ATE), 58.9\% male and $42.1 \%$ female. To obtain a representative sample, through 
sample calculation, considering $99 \%$ reliability and 5\% precision, the estimated necessary sample represented 338 participants. However, upon the invitation and presentation of objectives, 345 employees agreed to participate, making up the final sample of the present study.

The eligibility criteria for participating in the research were: being 18 years of age or older and being a university employee under the Legal Regime of Work. The exclusion criterion was to be away from work for any reason during the data collection period.

\section{Study protocol}

The research was formally authorized by the Rector of the present HEl. Subsequently, the management of the 12 educational centers were contacted via e-mail for the necessary clarifications and formalities to facilitate data collection. Soon, visits were made to the centers for negotiation regarding the appropriate times for applying the questionnaire.

Before collective applications, the objectives of the study, as well as the ethical aspects involved, were duly explained to potential participants. After these clarifications, the volunteers, who agreed to participate, by signing the FICF. After consent, they received an envelope containing the questionnaire with the self-completed instruments, which took about 20 minutes to be answered.

Data collection took place between June and October 2019, by the main researcher of the study and two properly trained and qualified research assistants for the face-to-face application of the research instrument.

\section{Data collection instrument}

To collect the data, a questionnaire was prepared containing the following instruments: a) Sociodemographic and work-related information. b) Alcohol Use Disorder Identification Test - Consumption (AUDIT-C). This instrument consists of three items that assess the amount (doses), frequency of alcohol consumption and consumption in the pattern of intoxication, or consumption in binge. For your reading, the levels of responses are added, ranging from zero to four points, later classified into levels of risk of consumption, such as low risk or abstainers and abusive or problematic use ${ }^{(15)}$.

c) Alcohol, Smoking and Substance Involvement Screening Test (ASSIST): questionnaire consisting of eight items, used to screen the level of use of alcohol, tobacco and other psychoactive substances. The questions address usage relationships, such as frequency, related problems, impairment in performing expected tasks, and unsuccessful attempts to cease or reduce consumption. ASSIST was validated in Brazil, showing good indexes of validity and internal consistency ${ }^{(16)}$.

d) Depression, Anxiety and Stress Scale (DASS-21): instrument that assesses symptoms of depression, anxiety and stress. The present scale is divided into three parts, being: (i) Depression: 3, 5, 10, 13, 16, 17, 21; (ii) Anxiety: 2, 4, 7, 9, 15, 19, 20; and, (iii) Stress: $1,6,8,11,12,14,18)$. The responses are of the Likert scale type with four points ( 0 does not apply in any way to 3 points, it applies a lot or most of the time) $)^{(17)}$. e) Dutch Fatigue Scale (DUFS) has been translated and validated for Brazilian Portuguese. The adapted versions of the DUFS contain eight items, respectively, arranged on a 5-point Likert scale. The scores on the items are added together to give a total score. For the final reading of the DUFS, item six was inverted before being added to the total scores, as the content of its statement has a negative meaning. A study shows good estimates of reliability by Chronbach's alpha $0.85^{(18)}$.

\section{Data analysis}

Statistical Package for the Social Science (SPSS) version 19 for Windows was used for statistical analysis. In the data analysis, descriptive statistics were used for calculations of frequency and percentage, to characterize the sample. The bivariate analysis of the data was performed using the Chi-Square Test $\left(X^{2}\right)$ to compare the categorical variables. To verify the distribution of variables in relation to the normal distribution, the Shapiro-Wilk test was used. Mann-Whitney $U$ test was also used for binary and Spearman Rho ( $r$ ) correlation variables. For all statistical tests, the significance level was set at $\mathrm{p}<0.05$.

\section{RESULTS}

345 workers participated in the study, adults with an average age of 38.9 years $(S D=10.5)$, ranging from 21 to 70 years. Of the total sample, 187 (54.2\%) were women, 163 (47.2\%) were single, 186 (53.9\%) professed the Catholic religion, 223 (64.8\%) had graduate school education. However, 122 (35.4\%) participants were still studying, in addition to working, and a minority, 19 (5.5\%), had another job (Table 1). They performed their function for an average of 9.9 years $(S D=10.3)$, ranging from less than one year to 42 years. One third of the workers indicated that their work was stressful $(35.4 \% \mathrm{n}=122)$.

The prevalence of use was: alcohol 301 (87.2\%), tobacco 145 (42\%), marijuana $73(21.2 \%)$, sedatives/hypnotics 30 (8.7\%) and amphetamines 5 (1.4\%). Regarding recent use, that is, in the last three months, there was a prevalence of alcohol use 275 (79.7\%), and in lower percentages among tobacco 64 (18.6\%), marijuana $23(6.7 \%)$, sedatives/hypnotics 14 (4.1\%), amphetamines 19 (5.5\%) in the present sample.

Of the participants, 101 (29.3\%) consumed alcohol at a problematic level in the last year (AUDIT-C), 72 (20.9\%) used the HED pattern at least once a week and 146 (45.2\%) had consumed in the binge pattern at least once a month in the last year. Of the sample, $60.3 \%$ of men and $49.7 \%$ of women consumed alcohol in the binge pattern, with statistically significant differences ( $p$ $\leq 0.001$ ). The weekly HED did not differ in relation to men (52.8\%) and women (47.2\%) ( $p$-value> 0.05).

When comparing age and the three consumption patterns, younger participants differed in relation to consumption in the HED pattern [Yes 35.9 years $( \pm 8.6)$ versus No 39.7 years $( \pm 10,9)$, $t=3.03$ IC95\% 6.13-1.33 ( $p=0.003)$ ]; pattern of consumption in binge, [Yes 34.9 years $( \pm 7,9)$ versus No 41.8 years $( \pm 11.2), t=6.37$ IC95\% 8.96-4.73 ( $p \leq 0.001)$ ] and in AUDIT C [low risk/abstainers 40.4 years $( \pm 11.2)$ versus problematic drinking/risk 35.1 years $( \pm 7.5), t$ $=4.36 \mathrm{IC} 95 \% 2.92-7.72(p \leq 0.001)]$, data not shown in the table. 
Table1 - Sociodemographic information, according to Administrative Technicians in Education ( $\mathrm{N}=345)$, Rio Grande do Sul, Brazil, 2019

\begin{tabular}{llc}
\hline & & $\mathbf{n}(\%)$ \\
\hline Gender & Female & $187(54.2)$ \\
& Male & $158(45.8)$ \\
Marital status & Single & $163(47.2)$ \\
& Married & $138(40.0)$ \\
Religion & Separated/divorced/widowed & $44(12.8)$ \\
& Catholic & $186(53.9)$ \\
& Evangelical & $21(6.1)$ \\
Education & Spiritism/other & $51(14.8)$ \\
& None & $87(25.2)$ \\
Study and work & High school & $20(5.8)$ \\
& Higher education & $101(29.4)$ \\
Has another employment & Graduate school education & $223(64.8)$ \\
relationship & No & $223(64.6)$ \\
& Sim & $122(35.4)$ \\
& No & $326(94.5)$ \\
& Sim & $19(5.5)$ \\
\hline
\end{tabular}

The use of alcohol in the binge pattern and HED were higher among workers with higher levels of anxiety, depression and stress (DAS) (Table 2). Alcohol consumption at risk levels (AUDIT-C) was higher in all DAS and DUFS measures. The consumption in binge and HED did not differ between those who had positive fatigue (DUFS).

When comparing stress and alcohol consumption, participants differed only in relation to the levels of consumption measured by the AUDIT-C. Of the participants who considered work to be stressful ( $n=122 ; 35.4 \%), 42 \%$ used alcohol at problematic levels, while $58 \%$ were abstinent or consumed at low risk (AUDIT-C) with statistically significant differences $(p=0.041)$. Of the participants, $42.1 \%$ consumed alcohol in the binge pattern and $43.1 \%$ in the HED, considered that work was stressful, but did not differ in relation to the sample ( $p>0.05$ ) (data not shown in the table).

It was also found that the participants who considered the work environment stressful had the highest average position among those classified as depression, anxiety, stress (DAS), fatigue (DUFS), with statistically significant values $(p \leq 0.05)$.

Table 2 - Comparison between the values of the average position between consumption, heavy episodic drinking (heavy episodic drinking, consumption in binge, and Alcohol Use Disorder Identification Test - Consumption) and anxiety, depression, stress (DAS) and fatigue (DUFS), according to the Administrative Technicians in Education. ( $=345)$, Rio Grande do Sul, Brazil, 2019

\begin{tabular}{lcccccc}
\hline & $\begin{array}{c}\text { HED } \\
\text { Average } \\
\text { position }\end{array}$ & $\begin{array}{c}\boldsymbol{p} \\
\text { value }\end{array}$ & $\begin{array}{c}\text { Binge } \\
\text { Average } \\
\text { position }\end{array}$ & $\begin{array}{c}\boldsymbol{p} \\
\text { value }\end{array}$ & $\begin{array}{c}\text { AUDIT-C } \\
\text { Average } \\
\text { position }\end{array}$ & $\begin{array}{c}\boldsymbol{p} \\
\text { value }\end{array}$ \\
\hline $\begin{array}{c}\text { Depression (DAS) } \\
\text { Yes }\end{array}$ & 198.01 & $0.007^{*}$ & 173.80 & $0.016^{*}$ & 193.29 & $0.006^{*}$ \\
$\quad$ No & 163.77 & & 149.34 & & 161.62 & \\
$\begin{array}{l}\text { Anxiety (DAS) } \\
\text { Yes }\end{array}$ & 201.94 & $0.002^{*}$ & 176.93 & $0.002^{*}$ & 199.21 & $\leq \mathbf{0 . 0 0 1 *}$ \\
$\quad$ No & 163.01 & & 146.25 & & 159.62 & \\
$\begin{array}{l}\text { Stress (DAS) } \\
\text { Yes }\end{array}$ & 202.11 & $0.004^{*}$ & 176.09 & $0.008^{*}$ & 196.22 & $0.003^{*}$ \\
No & 164.00 & & 148.57 & & 161.89 & \\
$\begin{array}{l}\text { Fatigue (DUFS) } \\
\text { Yes }\end{array}$ & 188.12 & 0.120 & 167.34 & 0.263 & 189.21 & $0.038^{*}$ \\
No & 167.72 & & 155.71 & & 164.82 & \\
\hline
\end{tabular}

Note: Mann-Whitney U test. p-value $\leq 0.05 ;$ HED - heavy episodic drinking; AUDIT-C - Alcohol Use Disorder Identification Test - Consumption; DAS - Depression, Anxiety and Stress; DUFS Dutch Fatigue Scale.
Table 3 - Comparison between alcohol consumption (AUDIT C), anxiety, depression, stress (DAS) and fatigue (DUFS), according to Administrative Technicians in Education, (N = 345), Rio Grande do Sul, Brazil, 2019

\begin{tabular}{lccc}
\hline & $\begin{array}{c}\text { Considers the work } \\
\text { stressful }\end{array}$ & $\begin{array}{c}\text { Average } \\
\text { position }\end{array}$ & $\begin{array}{c}\boldsymbol{p} \\
\text { value }\end{array}$ \\
\hline Depression (DAS) & No & 148.13 & $\leq \mathbf{0 . 0 0 1}$ \\
Anxiety (DAS) & Yes & 209.92 & \\
& No & 152.44 & $\leq \mathbf{0 . 0 0 1}$ \\
Stress (DAS) & No & 202.47 & \\
Fatigue (DUFS) & Yes & 153.73 & $\mathbf{5 0 . 0 0 1}$ \\
& No & 202.40 & \\
& & 150.72 & $\leq \mathbf{0 . 0 0 1}$ \\
\hline
\end{tabular}

Note: Mann-Whitney U test. P value $\leq 0.05$.

Table 4 - Analysis of correlation between Alcohol Use Disorder Identification Test - Consumption, age and length of professional practice time with anxiety, depression, stress (DAS) and fatigue (DUFS), according to Administrative Technicians in Education, ( $\mathrm{N}=345)$, Rio Grande do Sul, Brazil, 2019

\begin{tabular}{lcccc}
\hline & & AUDIT C & Age & $\begin{array}{c}\text { Length of } \\
\text { professional practice }\end{array}$ \\
\hline DUFS (Fatigue) & $r$ & 0.055 & -0.041 & -0.006 \\
Depression (DAS) & $r$ & 0.107 & -0.098 & 0.910 \\
Anxiety (DAS) & $P$ & 0.056 & 0.072 & -0.026 \\
Stress (DAS) & $R$ & $0.142^{*}$ & -0.065 & 0.627 \\
& $p$ & 0.011 & 0.233 & -0.005 \\
AUDIT C & $r$ & $0.128^{*}$ & $-0.152^{* *}$ & 0.930 \\
& $p$ & 0.022 & 0.005 & -0.099 \\
Age & $r$ & - & $-0.217^{* *}$ & 0.068 \\
& $p$ &. & $\leq 0.001^{*}$ & $-0.125^{*}$ \\
& $r$ & - & - & 0.025 \\
& & - &. & $0.740^{* *}$
\end{tabular}

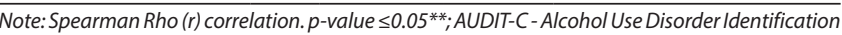
Test - Consumption; DAS - Depression, Anxiety and Stress; DUFS - Dutch Fatigue Scale

There are negative correlations between alcohol use (AUDIT) and stress $(r=-0.128, p=0.022)$ and positively with anxiety $(r=0.142, p=$ $0.011)$. These results suggest that the greater the stress and anxiety the greater the use of alcohol, or the reverse can also be considered.

Regarding age, an inverse correlation is observed, so as age increases $(r=-0.152, p=0,005)$ stress decreases, that is, stress may be occurring among younger people. In addition, negative correlations were noted between the use of alcohol and the length of professional practice. Thus, as age and working time increase, alcohol consumption decreases.

\section{DISCUSSION}

The results showed that the largest percentage of the sample were women (54.2\%), single (47.2\%), Catholics (53.9\%), with a graduate school education (64.8\%) and a long time service in the institution. A profile of workers compatible and required to perform the complex technical, administrative and managerial functions inherent to the proper functioning of a $\mathrm{HEl}$.

On the other hand, there are specific risk factors and workrelated stressors associated with "use" and "problematic use" of alcohol, for example, those entering the labor market, the high demands in short periods, the demands in the complexities of carrying out activities and the need to preserve work. Added 
to this, the possible insertion in groups of co-workers who consume alcoholic beverages, representing a specific problem for young adults who try to fit into a certain circle of friendship in the workplace ${ }^{(19)}$.

Substance use, in general, has been associated with several work situations, such as conflicting relationships and the workers' shared experience of the damage, risks and suffering generated by work, which commonly present an aspect of defensive practice. In other words, workers find in the use of substance, the relief to face various problems and suffering in life and especially stress ${ }^{(20)}$.

Alcohol was the substance of greatest use, with a prevalence of lifetime use of $87 \%$, problematic use of $29.3 \%$, use in the binge pattern (monthly) of $45.2 \%$ and in the HED pattern (weekly) of $20.9 \%$. These data show that the prevalence of lifetime use and binge use is partly similar to that of the general population, considering that most people have used alcoholic beverages at least once in their lives (experimental use) and the binge occurred mainly among younger males $(60 \%)^{(17)}$. Another important fact refers that in the southern region of Brazil, where the present study was carried out, the abstinence rates are lower, although they drink more frequently, the quantities are much lower ${ }^{(21)}$.

Alcohol by its depressive actions can result in lethargy in the command action and reaction, in the messages between the brain and the body. Thus, it affects the skills of problem solving, judgment, concentration, reaction times and coordination, causing negative consequences in the "ability to work" in the health and well-being in the short and long term ${ }^{(4)}$. In work environments, alcohol consumption has led to significant losses in productivity, resulting in absenteeism and, consequently, high numbers of dismissals ${ }^{(22)}$.

Evidence shows that individuals who use alcohol more intensively are more likely to develop social and health problems, and are concentrated among individuals of working age ${ }^{(23)}$. A study by the British Medical Association described that employed individuals are more likely to drink frequently when compared to those who are unemployed. And that those in managerial and professional positions are more likely to drink more frequently when compared to those in routine and manual occupations ${ }^{(24)}$.

Regarding age and alcohol use, it is worth noting that there is a high risk pattern among young adults aged 20 to 29 years, in both genders ${ }^{(16)}$, the age group with the highest level of employability. Still, the use of alcohol is the biggest risk factor associated with illness and premature deaths and increased costs of lost productivity, generating additional costs for institutions and reflecting on the country's economy ${ }^{(25)}$.

The abusive use of alcoholic beverages has an impact both in terms of health and social relationships ${ }^{(26)}$. This pattern of use reflects significantly in work relationships, compromising work safety, decreasing productivity, in addition to increasing absenteeism ${ }^{(27-28)}$.

At first, it was expected to find differences between consumption in the HED pattern in relation to gender (52.8\% men versus $47.2 \%$ women, $\mathrm{p}>0.05$ ), which was not observed in the present sample. However, it is worth noting that the three consumption patterns (risk consumption, HED and Binge) and the perception of work as stressful were associated with younger participants and with problems related to mental health (stress, anxiety, depression and fatigue). However, only the level of risky consumption (AUDIT-C) was higher among employees who found the work environment stressful. A study showed an association between alcohol use and high stress level, finding almost four times greater reasons for alcohol abuse. Thus, stress was understood as a significant risk factor for the consumption of alcohol, tobacco and other drugs ${ }^{(29)}$.

In addition, self-reported problems due to the use of alcoholic beverages according to a survey conducted with civil servants showed a significant association with depression. The workers interviewed who reported having problems related to alcohol use, were 2.76 times more likely to have depression than those who did not report this situation ${ }^{(9)}$.

Although, data from the report of the World Health Organization show that the prevalence of consumption in the HED pattern has decreased globally since 2000 , the prevalence of this pattern of use has not differed between countries, especially between men and younger people ${ }^{(1)}$. Thus, alcohol abuse still needs to be treated as a problem that threatens health, wellbeing and safety in different social settings, demanding urgent responses to public policies and preventive actions.

\section{Study limitations}

The study's limitation is the fact that employees were not asked directly about the losses caused by heavy consumption, as well as whether this consumption interferes with work relationships, such as: being late, missing the work day, suspension, warnings, alcohol use and the physical consequences caused by consumption. In addition, the evaluation of other variables related to the perception of stress and alcohol use, such as: drinking to relax and drinking to relax after a stressful day at work and satisfaction with the work. Furthermore, no matter how much association analysis has been used, considering that this is a cross-sectional study, causality cannot be considered, other types of methodologies are necessary.

\section{Contributions to the field of nursing, health or public policy}

The study contributed to identify issues related to alcohol use, stress, anxiety and the context of the work of employees to provide subsidies for implementing health strategies and interventions in the workplace. For the public policies, it presents the possibility of reaching different realities and populations to guide/educate towards a critical and responsible awareness for use. Thus, there is a belief in a comprehensive health care practice, which considers the person in his/her uniqueness, which can influence and be influenced by the social environment in which he/she lives.

\section{CONCLUSION}

The study showed that alcohol use in the binge pattern (monthly) and HED (weekly) were higher among workers with higher levels of anxiety, depression and stress. The participants who considered the work environment stressful presented, 
with significant statistical values, the position of the highest average among those classified with depression, anxiety, stress and fatigue.

Another relevant result obtained concerns age, an inverse correlation is observed, so as age increases, stress decreases, that is, stress may be occurring among the youngest. The relationship between alcohol use and length of professional practice also showed a negative correlation. Thus, as age and time increase, alcohol consumption decreases.

It concludes by recognizing that the research findings referring to alcohol use, stress, depression and anxiety in work environments bring particularities that must be evaluated and recognized as a challenge for public health, considering the rates of problems associated with alcohol use, age and stress.

\section{REFERENCES}

1. World Health Organization (WHO). Global status report on alcohol and health 2018 [Internet]. Geneva: WHO; 2018[cited 2020 Feb 12]. Available from: https://www.who.int/substance_abuse/publications/global_alcohol_report/en/

2. Organização Pan-Americana da Saúde (OPAS), Organização Mundial da Saúde (OMS Brasil). Folha informativa - Álcool. Brasília: OPAS; 2019.

3. Felix Jr IJ, Schlindwein VLDC, Calheiros PRV. A relação entre o uso de drogas e o trabalho: uma revisão de literatura. Estud Pesqui Psicol [Internet]. 2016 [cited 2020 Feb 12];16(1):104-22. Available from: http://pepsic.bvsalud.org/scielo.php?script=sci_abstract\&pid $=$ S1808-42812016000100007

4. Dimenstein M, Lima AIO, Figueiro RA, Leite JF. Uso abusivo de álcool e outras drogas entre trabalhadores do sistema prisional. Rev Psicol Organ Trab. 2012;17(1):62-70. doi: 10.17652/rpot/2017.1.12705

5. Frone MR, Brown AL. Workplace substance-use norms as predictors of employee substance use and impairment: a survey of U.S. workers. J Stud Alcohol Drugs. 2010;71(4):526-34. doi: 10.15288/jsad.2010.71.526

6. Victorian Heath Promotion Foundation (VicHealth). Reducing alcohol-related harm in the workplace (An evidence review: summary report), Victorian Heath Promotion Foundation, Melbourne, Australia: 2012. 28p.

7. Serviço Social da Indústria (SESI). Dados sobre o uso de álcool e outras drogas no trabalho [Internet]. 2013[cited 2020 Feb 12]. Available from: http://www.sesipr.org.br/cuide-se-mais/alcool-e-outras-drogas/dadossobre-o-uso-de-alcool-e-outras-drogas-notrabalho-1-23999-216358.shtml

8. Serviço Social da Indústria (SESI). Prevenção ao uso de álcool e outras drogas. Curitiba; 2015. p. 1-15.

9. Gavin RS, Reisdorfer E, Gherardi-Donato ECS, Reis LN, Zanetti ACG. Association between depression, stress, anxiety and alcohol use among civil servants. SMAD, Rev Eletrôn Saúde Mental Alcool Drogas[internet]. 2015[cited 2019 Nov 21];11(1):2-9. doi: 10.11606/issn.1806-6976. v11i1p2-9

10. Santana LL, Sarquis LMM, Miranda FMA, Kalinke LP, Felli VEA, Miniel VA. Health indicators of workers of the hospital area. Rev Bras Enferm. 2016;69(1):23-32. doi: 10.1590/0034-7167.2016690104i

11. Junqueira MAB, Ferreira MCM, Soares GT, Brito IE, Pires PLS, Santos MA, et al. Alcohol use and health behavior among nursing professionals. Rev Esc Enferm USP. 2017;e03265:1-8. doi: 10.1590/S1980-220X2016046103265

12. Bertussi VC, Junqueira MAB, Giuliani CD, Calçado RM, Miranda FJS, Santos MA, et al. Substâncias psicoativas e saúde mental em profissionais de enfermagem da Estratégia Saúde da Família. Rev Eletrôn Enferm. 2018;20:v20a21. doi: 10.5216/ree.v20.47820

13. Junqueira $M A B$, Santos $M A$, Araújo $L B$, Ferreira MCM, Giuliani CD, Pillon SC. Depressive symptoms and drug use among nursing staff professionals. Esc Anna Nery. 2018;22(4):e20180129. doi: 10.1590/2177-9465-EAN-2018-0129

14. National Institute on Alcohol Abuse and Alcoholism (NIAAA). NIAAA Council Approves Definition of Binge Drinking. NIAAA Newsletter, No. 3, Winter [Internet]. 2004[cited 2019 Nov 22]. Available from: http://pubs.niaaa.nih.gov/publications/Newsletter/winter2004/Newsletter

15. Carretero MAG, Ruiz JPN, Delgado JMM, González CO. Validación del test para la identificación de trastornos por uso de alcohol en población universitaria: AUDIT y AUDIT-C. Adiccion. 2016;28(4):194-204. doi: 10.20882/adicciones.775

16. Henrique IFS, De Micheli D, Lacerda RB, Lacerda LA, Formigoni MLOS. Validation of the Brazilian version of Alcohol, Smoking and Substance Involvement Screening Test (ASSIST). Rev Assoc Med Bras. 2004;50(2):199206. doi: 10.1590/S0104-42302004000200039

17. Vignola RC, Tucci AM. Adaptation and validation of the depression, anxiety and stress scale (DASS) to Brazilian Portuguese. J Affect Disord. 2014;155:104-9. doi: 10.1016/j.jad.2013.10.031

18. Tiesinga LJ, Dassen TW, Halfens, RJ. DUFS and DEFS: Development, reliability and validity of the Dutch Fatigue Scale and the Dutch Exertion Fatigue Scale. Int J Nurs Stud [Internet]. 1998 [cited 2019 Nov 20];35(1-2):115-23. Available from: http://www.ncbi.nlm.nih.gov/ pubmed/9695018

19. Bray JW, Galvin DM, Cluff LA, eds. Young adults in the workplace: a multisite initiative of substance use prevention programs. RTI Press publication No. BK-0005-1103[Internet]. Research Triangle Park, NC: RTI Press. 2011 [cited 2019 Nov 20]:159p. Available from http://www.rti. org/rtipress

20. Jardim SR, Ramos A, Glina DMR (2014). Diagnóstico e nexo com o trabalho. In Glina DMR, Rocha LE (Orgs.). Saúde mental no trabalho: da teoria à prática. pp. 49-80. São Paulo: Roca. 
21. Instituto Nacional de Ciências e Tecnologia para Politicas Publicas do Álcool e Outras Drogas (INPAD). II LENAD. Levantamento Nacional de Álcool e Drogas. Universidade Federal de São Paulo: UNIFESP; 2012.

22. Backhans MC, Lundin A, Hemmingsson T. Binge drinking--a predictor for or a consequence of unemployment? Alcohol Clin Exp Res. 2012;36(11):1983-90. doi: 10.1111/j.1530-0277.2012.01822.x

23. Institut of Alcohol studies (IAS). Alcohol in the workplace. Factsheet Series [Internet]. 2016 [cited 2019 Nov 20]. 13p. Available from: http:// www.ias.org.uk

24. Trades Union Congress (TUC). Changing the word of work for good. Drugs and alcohol in the workplace: guidance for workplace representatives[Internet]. 2019 [cited 2019 Nov 20]. 8p. Available from: https://www.tuc.org.uk/sites/default/files/ drugsalcoholinworkplace.pdf

25. Santana LL, Sarquis LMM, Brey C, Miranda FMD, Felli VEA. Absenteeism due to mental disorders in health professionals at a hospital in southern Brazil. Rev Gaúcha Enferm. 2016;37(1):e53485. doi: 10.1590/1983-1447.2016.01.53485

26. Carmo DRP, Faria FL, Pelzer MT, Terra MG, Santos MA, Pillon SC. Motivation attributed by adults to the consumption of alcoholic beverages in the social contexto. Rev Psicol: Teor Prát. 2018;20(2):240-53. doi: 10.5935/1980-6906/psicologia.v20n2p240-253

27. World Health Organization (WHO). Global status report on alcohol and health 2014 [Internet]. Geneva: WHO; 2014 [cited 2019 Nov 20]. Available from: https://www.who.int/substance_abuse/publications/alcohol_2014/en/

28. Ferro LRM, Trigo AA, Oliveira AJ, Almeida MAR, Tagava RF, Meneses-Gaya C, et al. Estresse percebido e o uso de álcool, tabaco e outras drogas entre universitários. Saúde Pesqui. 2019;12(3):573-81. doi: 10.17765/2176-9206.2019v12n3p573-581 